Tina Lengar Verovnik

Fakulteta za družbene vede Univerze v Ljubljani

Inštitut za slovenski jezik Frana Ramovša ZRC SAZU, Ljubljana

\title{
Strategije in sredstva leksikalnega kritja v radijskih intervjujih
}

Prispevek prinaša analizo govora novinarjev v intervjujih z dveh programov slovenskega javnega radijskega servisa $\mathrm{z}$ vidika rabe strategij in sredstev leksikalnega kritja. Pri tem so upoštevane žanrske in diskurzivne okoliščine, ki tudi sicer določajo novinarjev govor. Rezultati so zaradi ugotavljanja (ne)tipičnosti posameznih skupin sredstev leksikalnega kritja za radijske intervjuje primerjani z gradivom iz korpusa pisnih besedil Gigafida in korpusa govorjenega jezika GOS. Razvoj koncepta leksikalnega kritja in oris dosedanjih raziskovanj sta predstavljena $\mathrm{v}$ začetnem delu prispevka, prav tako tudi utemeljitev slovenskega prevoda izvornih izrazov hedging in (to) hedge.

This contribution examines hedging strategies and devices employed by journalists in selected interviews from two Slovene public radio programmes. Genre and discourse frameworks are taken into account, as they determine journalists' linguistic choices in general. The results are then compared to those from two Slovene language corpora, namely Gigafida (corpus of written texts) and GOS (corpus of oral communication), in order to determine how typical of radio interviews the hedging devices in question are. In the first section of the paper a brief account of the evolution of hedging as a concept and an overview of the past and recent research in the field are given as well as the arguments for the Slovene translation of the terms hedging and (to) hedge.

\section{Uvod}

Leksikalno kritje ${ }^{1}$ (angl. hedging) je bilo izvorno opredeljeno kot raba jezikovnih sredstev, »katerih vloga je stvari v besedilu zamegliti ali jih narediti razvidnejše« (Lakoff 1972: 195). Prvotna definicija pojava je ob širjenju področij raziskovanja doživljala mnoge konceptualne dopolnitve in spremembe. Čeprav so posamezne opredelitve odvisne tudi od raziskovalčevega namena, metode raziskovanja in tipa diskurza, se pojem leksikalno kritje $\mathrm{v}$ sodobnih virih nanaša pretežno na prvi del izvorne definicije.

${ }^{1}$ Izraz »leksikalno kritje« je bil uporabljen že v Lengar Verovnik (2012). Utemeljitev prevoda sledi v poglavju 1. 
Sredstva leksikalnega kritja niso zaključena množica leksemov in skladenjskih zgradb (ter v govoru prozodijskih sredstev). Skupno jim je, da delujejo kot opozorilo govorca/pisca, da želi bodisi omejiti vsebino bodisi ublažiti ilokucijsko moč povedanega. Nobeno jezikovno sredstvo torej ni samo po sebi sredstvo leksikalnega kritja, ampak to postane šele $\mathrm{v}$ določenem sporočanjskem kontekstu in je za tak kontekst tudi tipično (medtem ko lahko v drugih kontekstih opravlja druge vloge). Prav tako se proučevanje leksikalnega kritja ne omejuje le na eno področje ali raziskovalno perspektivo, temveč ga kot osrednji ali obrobni pojav zajemajo npr. študije izražanja (ne)vljudnosti, analize znanstvenega diskurza, medjezikovne in medkulturne analize, pristopi k poučevanju tujih jezikov, študije jezikovnih razlik glede na spol govorca ter primerjalne analize govora in pisanja oziroma raziskave zgolj govora.

Radijski intervjuji predstavljajo govorjeni diskurz, $v$ katerem je novinar kot spodbujevalec pogovora med drugim zavezan empatičnosti do sogovorca in občinstva, kar pomeni veliko verjetnost za rabo strategij in sredstev leksikalnega kritja. Kljub temu dejstvu je raziskav medijskega diskurza nasploh, dvogovornega pa še posebej, ki bi vključevale ta vidik, zelo malo. V prispevku bomo najprej utemeljili slovenski prevod »leksikalno kritje«, natančneje pregledali genezo koncepta ter orisali aktualna področja, metode in cilje raziskovanja. V empiričnem delu bomo na gradivu radijskih intervjujev s slovenskega javnega servisa analizirali primere leksikalnega kritja, jih kategorizirali glede na njihove pojavne oblike in z upoštevanjem diskurzivnih okoliščin poskušali utemeljevati motive zanje. S primerjavo z gradivom iz pisnega korpusa Gigafida in korpusa govorjene slovenščine GOS bomo preverjali tudi njihovo (ne)prekrivnost $\mathrm{z}$ rabo v pisnih in drugačnih govorjenih diskurzih.

\section{Utemeljitev slovenskega prevoda izraza hedging}

V angleški literaturi se je kot krovni pojem za zgoraj opisane strategije uveljavil izraz hedging, jezikovno sredstvo, s katerim se hedging udejanji, pa se imenuje hedge; redkeje je rabljen še glagol to hedge. Veliki angleško-slovenski slovar (Gabrovšek in dr. 2005) pri geslih hedging in hedge navaja naslednje pomene:

\section{hedging}

1 živa meja; 2 urejanje žive meje; 3 izmikanje; 4 FIN. hedging, kritje tveganja, varovanje pred tveganjem

\section{hedge}

I sam. 1 živa meja, ograja, pregrada; 2 FIN. varovanje pred izgubo/tveganjem, pokritje tveganja; 3 izmikanje, splošen/nedoločen odgovor

II preh. glag. 1 ograditi, obkrožiti; $\mathbf{2}$ izogniti se, izmakniti se; 3 FIN. zaščititi, zavarovati; 4 omejiti

III nepreh. glag. 1 izogniti se, izmakniti se; 2 vzdrževati živo mejo; 3 FIN. zaščititi se, zavarovati se 
Lakoff je začel pojav raziskovati v zvezi s t. i. mehkimi množicami (angl. fuzzy sets) in ga prenesel na izražanje neizrazitosti mej med kategorijami nasploh. Tako kot za pingvina lahko rečemo, da je »neke vrste ptica « (angl. sort of bird), medtem ko je taščica prototipični predstavnik kategorije "ptič« (angl. bird par exellence), lahko tudi vse druge propozicije vsebinsko omejimo z jezikovnimi sredstvi tipa nekako, precej, do neke/določene mere ipd. Sprva so se v raziskavah omejevali na jezikovna sredstva $\mathrm{z}$ vidika semantike in ne na celovite strategije oziroma njihove pragmatične učinke in vloge. Zato je izraz hedge sprva vseboval izrazito asociacijo na izvorni pomen žive meje, kar dokazujeta denimo nemški prevod Heckenausdruck oz. sprachliche Hecke (dobesedno pomeni Hecke živo mejo) in poimenovanje sorodnih konceptov pri npr. Caffi (po Fraser 2010a: 20-21) kot bushes (grmovje) in shields (zasloni, ščiti).

V začetku so v okviru koncepta proučevali tudi nasprotni pojav, ko ne gre za omilitev, temveč ojačitev vsebine propozicije, npr. »absolutna resnica« (angl. absolute truth). Kasneje se je za jezikovna sredstva s takim semantičnim učinkom začelo uporabljati izraz booster, ki ga Pisanski Peterlin (2007) prevaja kot »ojačevalec«. Ista avtorica izraz hedge prevaja kot »omejevalec«, kar je skladno z izvornim pojmovanjem koncepta in poimenovalno ustreza pojavom, ki jih sama proučuje v znanstvenem pisanju. Vendar pa je hedging, kot bo pokazano v naslednjem poglavju, postal veliko širši in bolj raznoroden pojav, zato prevod »omejevanje« pomensko ne ustreza.

Pri iskanju ustreznega prevoda smo izhajali iz gradiva, ki bo predstavljeno v nadaljevanju, ob katerem je bilo ugotovljeno, da ne gre zgolj za »izmikanje«, »izogibanje« ali »splošno/nedoločno izražanje« (kar so možni prevodi glede na zgoraj prikazane slovarske rešitve). Bolj kot za izmikanje pred odgovornostjo za izbrana leksikalna sredstva ali za ubesedeno propozicijo gre namreč v obravnavanem gradivu za strategijo iskanja ustreznega zavarovanja pred tveganjem - tveganjem, da se bo izbor jezikovnega sredstva izkazal kot neustrezen, neuspel, ali pa tveganjem, da je bila neka propozicija neustrezno ubesedena ali sploh neprimerno izbrana. Ker je v angleščini hedging v štirih desetletjih jezikoslovne rabe doživel korenito pomensko širitev in odmik od izvorne pomenske motivacije, se je zdelo smiselno tudi pri slovenskem izrazu opreti na že izpeljani pomenski prenos. Gre za finančne rabe izrazov hedging in hedge, pri katerih je v ospredju prav zaščita, zavarovanje pred tveganjem in izgubo. Izraz »kritje« je glede na »zaščito《 in »zavarovanje« pomensko manj zaseden in tudi natančnejši (glede na nameravani pomen izraza). Pridevnik »leksikalni« kot razlikovalna prvina sicer ne pokriva celotne raznolikosti jezikovnih sredstev, ki udejanjajo to kritje, saj gre v resnici za leksikalne, leksikalno-skladenjske, oblikoslovne, skladenjsko-prozodične ali samo prozodične pojave, vendar pa je raven leksike v središču in stičišču vseh proučevanj, ki se leksikalnega kritja lotevajo kot osrednjega ali zgolj obrobnega pojava. 


\section{Pregled raziskovanj leksikalnega kritja}

Leksikalno kritje in z njim povezana jezikovna sredstva so $\mathrm{v}$ štirih desetletjih doživela mnogo obravnav s teoretičnega, empiričnega in uporabnega vidika. Pregledno se lahko o tem podučimo denimo v Fraser (2010a; 2010b), Crompton (1997) ali Farr in O'Keeffe (2002). Danes leksikalno kritje za razliko od zgoraj omenjene izvorne Lakoffove definicije opredeljujejo kot »diskurzivno strategijo, ki zmanjša moč ali omeji vsebino izjave in s tem zmanjša tveganje, ki bi ga govorec nosil ob nezmanjšani moči ali neomejeni vsebini izjave« (Kaltenböck in dr. 2010: 1), oziroma kot retorično strategijo, pri kateri »z rabo določenega izraza, skladenjske zgradbe ali prozodične izpeljave govorec signalizira bodisi omejeno pripadnost kategoriji, ko gre za določen izraz ali besedno zvezo (oslabitev vsebine), ali zmanjšanje nameravane ilokucijske moči izjave (oslabitev izjavne moči). Povedano enostavneje, leksikalno kritje oslabi vrednost izjave, kakršno bi ta imela brez sredstev leksikalnega kritja « (Fraser 2010b: 201).

Sredstva leksikalnega kritja so prepoznana kot taka šele, ko jih uporabimo za leksikalno kritje. Razen zgoraj opisanega učinkovanja nimajo skupne slovnične ali kategorialne točke, saj gre lahko za oblikoslovne morfeme ali kategorije, lekseme ali besedne zveze, skladenjske zgradbe, $\mathrm{v}$ govoru tudi diskurzivne označevalce (gl. Verdonik 2007 in drugod) ali celo neverbalne prvine (vzdihi in drugi zvoki, kretnje in mimika). Ne glede na to pa se posamezne raziskave osredotočajo bodisi na:

- posamezne besede ali zveze (v angleščini pogosto raziskovana izraza sta npr. sort of in kind of, gl. Fetzer 2010; Gries in David 2007);

- slovnične kategorije, ki opravljajo vlogo sredstev leksikalnega kritja (prislovi, naklonski glagoli, trpniške zgradbe ipd.; za popolnejši seznam gl. Fraser 2010a: 23-25);

- vloge, ki jih opravljajo sredstva leksikalnega kritja, oziroma njihovo združevanje v podkategorije (npr. omiljevalci, zaznamovalci vljudnosti, razpršsevalci, opozarjalci ipd.; za popolnejši seznam gl. Fraser 2010b: 203);

- doseg sredstev leksikalnega kritja (beseda, besedna zveza, poved, nameravana ilokucijska moč ali perlokucijski učinek izjave);

- njihove diskurzivne rabe glede na sporočanjski namen (za izražanje (ne)vljudnosti, izogibanje odgovornosti, blaženje učinka izjave, vzbujanje vtisa skromnosti, opravičevanje, nedoločnost ipd.);

- učinke njihove rabe na naslovnika (v smislu avtoritete, privlačnosti, kredibilnosti ipd.);2

- specifike leksikalnega kritja v posameznih zvrsteh, žanrih in govornih položajih ter glede na spol govorcev.

${ }^{2}$ Jalilifar in Alavi (2011: 46) navajata študijo Partona in dr. iz leta 2002, v kateri so ugotavljali povezavo med pogostnostjo sredstev leksikalnega kritja in zaznamovalcev oklevanja ter njihovim učinkom na sogovornika. Govorcem z višjo pogostnostjo teh jezikovnih sredstev v govoru sta se pripisovali manjša zaposljivost in kompetentnost, po drugi strani pa se je govorcem z nižjo pogostnostjo pripisovala manjša družbena privlačnost oziroma zaželenost (kar posredno kaže na povezavo med leksikalnim kritjem in vljudnostjo). 
Ugotovitve nekaterih usmerjenih raziskav bomo na ustreznih mestih in za osvetlitev najdenih pojavov vključevali $\mathrm{v}$ diskusijo ob rezultatih. $\mathrm{V}$ tem poglavju pa bodo na kratko predstavljene le ključne ugotovitve raziskav iz zadnje skupine.

$\mathrm{V}$ znanstvenih besedilih je leksikalno kritje dobro raziskan pojav. V slovenskem prostoru ga je v okviru koncepta metabesedilnosti proučevala Pisanski Peterlin (2007). Slovenski pisci v tej vlogi uporabljajo izraze, kot so npr. domnevno, domnevati, predvidevati, morda, možno, do neke/določene mere, zdi se, verjetno, večinoma, tako rekoč. S sredstvi leksikalnega kritja pisec eksplicitno opredeli stopnjo lastnega prepričanja $\mathrm{v}$ resničnost trditve, ki jo tako sredstvo modificira. Leksikalno kritje je značilno za znanstveno pisanje, ki prinaša nova spoznanja, ki jih mora znanstvena diskurzivna skupnost šele oceniti (ne pa npr. za učbeniška besedila, ki prinašajo dejstva, sprejeta v neki znanstveni skupnosti). Zaznamuje torej začasnost spoznanj oziroma védenja; z njim pisec nakazuje, da si pridržuje pravico, da se kdaj kasneje vrne $\mathrm{k}$ trditvi, jo spremeni, popravi, dopolni ipd. Lahko pa je tudi neke vrste vljudnostna strategija - ker avtor z novimi dejstvi, trditvami, odkritji »ogroža« spoznanja drugih, njihovo ilokucijsko moč omili s pomočjo sredstev leksikalnega kritja. Poos in Simpson (2002) ugotavljata, da je tako iskanje ravnotežja med avtoritativnostjo in popustljivostjo značilno za akademsko izražanje v vseh disciplinah, še posebej pa to velja za humanistična in družboslovna področja.

Primerjalne študije rabe sredstev leksikalnega kritja v prevodnih besedilih so pokazale, da različni jeziki uporabljajo različna leksikalna in skladenjska sredstva, z različno pogostnostjo rabe. To le še potrjuje siceršnje ugotovitve, da ne gre za zaključeno množico sredstev in da je leksikalno kritje - kot kaže - produktiven jezikovni koncept. Pisanski Peterlin (2010) v primerjalni študiji izvirnih in prevodnih besedil v slovenščini in angleščini ugotavlja, da obstajajo med jezikoma medkulturne razlike, ki pa se pri prevajanju na ravni leksikalnega kritja izgubijo, saj vsebujejo prevodna besedila pol manj tovrstnih jezikovnih sredstev, ki so tudi manj raznolika kot v izvirnikih. ${ }^{3} \mathrm{Na}$ pomen učenja pragmatičnih razsežnosti tujega jezika na ravni leksikalnega kritja opozarjajo med drugimi tudi Fraser (2010a: 15-16) ter Farr in O'Keeffe (2002), saj lahko posamezniki kljub visoki slovnični zmožnosti v tujem jeziku zaradi socio-kulturnih razlik oziroma njihovega nepoznavanja nehote delujejo nevljudno, arogantno, celo žaljivo.

Po tezi v Lakoff (1975), da naj bi ženske leksikalno kritje uporabljale pogosteje kot moški (kar je avtorica utemeljevala na introspektivnem opazovanju), se je raziskovanje usmerilo tudi v razlike glede na spol. Gradivne raziskave jih ne potrjujejo (npr. Bradac, Mulac in Thompson 1995; za empirične primere gl. Poos in Simpson 2002). Poleg tega siceršnje raziskovanje leksikalnega kritja kaže, da ga ne gre povezovati s šibkostjo, feminilnostjo ali spoštljivostjo; pogosto je znak moči in takta. Vedno pa je treba pri gradivnem raziskovanju upoštevati tudi individualne razlike med

${ }^{3}$ Za členke, ki se deloma uvrščajo med sredstva leksikalnega kritja, tudi Žele (2014: 9) ugotavlja, da so »smiselne besed(ic)e s pragmatično močjo, ki jih znamo smiselno besedilno uporabljati zlasti v svojem prvem jeziku«. 
govorci in vpliv neposrednih okoliščin sporočanja oziroma širšega konteksta. V tem smislu je denimo zanimiva ugotovitev Jalilifarja in Alavija (2011), da nosilci politične moči v političnih intervjujih uporabljajo leksikalno kritje v obratnem sorazmerju s svojo politično močjo.

\section{Gradivo in metodologija}

Pri raziskovanju leksikalnega kritja v političnih ali novičarskih intervjujih se avtorji večinoma osredotočajo na govor gostov (gl. npr. Jalilifar in Alavi 2011; Fraser 2010b), ne pa na govor novinarjev. V tem prispevku se bomo - nasprotno - omejili na govor novinarjev oziroma govorcev, ki jim ustanova v času govornega dogodka (radijskega intervjuja) podeljuje institucionalno vlogo novinarja ${ }^{4}$. Strinjamo se z ugotovitvijo Farr in O'Keeffe (2002), da se leksikalno kritje poraja iz okoliščin rabe, ki pogosto presegajo neposredni kontekst in jih zaznamuje širši sociokulturni okvir govorne interakcije. Zato bomo v tem poglavju najprej na kratko opredelili žanrske in diskurzivne značilnosti radijskega intervjuja ter vlogo novinarja v njem (3.1). V analizi se bomo omejili na govor novinarjev v radijskih intervjujih s prvega in drugega progama Radia Slovenija (podrobnejša predstavitev gradiva je v 3.2), rezultate pa bomo primerjali z gradivom iz korpusov Gigafida in GOS (3.3).

Za primerjavo z gradivom iz obeh korpusov smo se odločili, da bi preverili, katera sredstva leksikalnega kritja so (bolj) tipična za radijske intervjuje, katera pa se nemara pogosteje pojavljajo v pisnih in/ali drugačnih govorjenih diskurzih. Pri tem se zavedamo omejitev iskanja po korpusnem gradivu (predstavljene bodo ob posameznih sklopih v poglavju 4), ki izvirajo bodisi iz zmogljivosti spletnega vmesnika bodisi iz večpomenskosti in večfunkcijskosti posameznih sredstev leksikalnega kritja. $\mathrm{V}$ radijskih intervjujih smo jih kot take opredelili s pomočjo natančne jezikovne analize transkribiranih besedil, ob upoštevanju kontekstualnih in diskurzivnih okoliščin (gl. 3.1 in 3.2). Tudi pri obeh korpusih so te okoliščine delno zajete $\mathrm{z}$ uvrstitvijo posameznega izseka iz pisanja ali govora $\mathrm{v}$ določeno vrsto pisnega besedila (leposlovje, stvarna besedila, časopisi, revije, internet) oziroma govorjenega diskurza (javni informativno-izobraževalni/razvedrilni, nejavni nezasebni/zasebni), podrobneje še npr. z medijem, letom nastanka, reginalno pripadnostjo govorca ipd. Vendar pa še zdaleč ne moremo govoriti o primerljivih informacijah v obeh gradivnih delih (radijskih intervjujih in korpusnem gradivu) niti ne bomo korpusnega gradiva natančneje besedilno analizirali, čeprav bi takšna analiza posameznih konkodranc rezultate gotovo izboljšala. Primerjava pri posameznih skupinah leksikalnih sredstev v poglavju 4 torej kaže le približno sliko (ne)tipičnosti leksikalnih sredstev v radijskih intervjujih, hkrati pa je vir idej za nadaljnje raziskovanje.

${ }^{4}$ Tvorci besedil oziroma pobudniki dvogovorov v novinarskih diskurzih niso vedno diplomirani novinarji, vendar pa $\mathrm{v}$ intervjujih nujno privzemajo vlogo novinarja, torej delujejo $\mathrm{v}$ skladu s formalno in neformalno pridobljenimi novinarskimi znanji. 


\subsection{Raziskovalni okvir}

Primarna funkcija vseh novinarskih diskurzov je obveščanje javnosti o zanjo relevantnih in družbeno pomembnih zadevah. Novinarski intervju to dosega skozi dvogovor, ki se ustvarja $z$ vnaprej dogovorjenim pogovorom med novinarjem in drugimi udeleženci, ki so med pogovorom (razen ko gre za telefonski intervju) tudi v neposrednem stiku. Korošec (1998: 251-253) dvogovor opredeljuje kot prvinsko obliko človekove jezikovne dejavnosti med (navadno) dvema osebama, pri kateri prepoznava dva osnovna tipa: enosmerni dvogovor, kjer samo ena oseba izraža spodbude, in obojesmerni dvogovor, kjer je vloga spodbujevalca izmenična. Za intervjujski dvogovor je značilna prva situacija.

Novinarjeve vloge $\mathrm{v}$ radijskem intervjuju so opredeljene $\mathrm{v}$ trikotniku novinar sogovorec - poslušalec. Novinar je lahko motivator, spodbujevalec sogovorca, in sicer takrat, ko upošteva predvsem njegove interese oziroma vsebino in informacije, ki bi jih ta rad sporočil; v vlogi interpreta nastopa, kadar je enako dobro informiran kot sogovorec, med njima se ustvari dialog $\mathrm{v}$ pravem pomenu besede; novinar lahko nastopa tudi v vlogi zastopnika poslušalca, če ima natančno predstavo o ciljni skupini, ki ji je intervju namenjen. Kljub temu, da sta za uspešnost komunikacije odgovorna oba (oziroma vsi, kadar je sogovorcev več), pa zavedanje komunikacijskega trikotnika novinar - sogovorec - poslušalec pomaga predvsem novinarju, ko se pripravlja na izvedbo intervjuja.

Pomembna prvina dobrega intervjuja je sposobnost empatije, vživljanja v sogovorca (več o tem v Košir 1988; Laban 2007). Ta vključuje aktivno poslušanje sogovorca in smiselno odzivanje na njegove odgovore. Radijski intervjuji so načeloma daljši kot televizijski, namenjene so jim lahko celotne (redne) oddaje, torej imajo radijski novinarji več časa in možnosti za poglobljene, bolj temeljite in empatične prispevke. Ker je pri radijskem intervjuju za razliko od intervjuja v tisku naslovniku izkustveno dostopen tudi proces nastajanja (in ne le rezultat predhodnega novinarskega dela), predvideva njegova izvedba dobro obvladovanje raznolikih spretnosti in znanj, ki občinstvu niso vidna; viden oziroma slušen je pri dobro izvedenem intervjuju le splošni vtis, da je intervjuvanje preprosto opravilo.

Odnos med udeleženci intervjuja oziroma razmerje (družbeno, institucionalno), ki se med njimi vzpostavlja, pomembno sooblikuje jezikovne izbire. Tudi dejstvo, da razen neposrednih sogovorcev obstaja še občinstvo, ki lahko pogovor sliši (ni pa v njem aktivno udeleženo), pomembno vpliva na oblikovanje izjav (Verschueren 2000: 124). Še bolj kot to pa na izbire vpliva institucija, v okviru katere deluje radijski govorec.$^{5} \mathrm{~V}$ našem primeru je to javni servis, ki zaradi svojega družbenega pomena medijskim govorcem postavlja jasen jezikovno- in splošnokulturni okvir, ekspliciran $\mathrm{v}$ zunanjih in notranjih pravnih aktih, ki regulirajo njegovo delovanje.

${ }^{5} \gg$ Včasih mora biti samo jezikovno izbiranje institucionalno odobreno /.../. V takih primerih govorimo o potrjenih izjaviteljih in potrjenih interpretih /.../« (Verschueren 2000: 136). 


\subsection{Izbrani radijski intervjuji}

Gradivo za raziskavo predstavlja del intervjujev, zbranih za celovito jezikovno-stilno analizo govora novinarjev $\mathrm{v}$ dvogovornih novinarskih žanrih (poleg intervjujev še pogovorov) $\mathrm{z}$ različnih tipov radijskih programov (poleg javnih še zasebnih nepridobitnih, komercialnih in alternativnih), ki je objavljena v Lengar Verovnik (2012). Strategije in sredstva leksikalnega kritja bomo analizirali v 29 intervjujih s programov javnega RTV-servisa Slovenija 1 in Val 202. Posnetki so bili pridobljeni iz javno dostopnega spletnega arhiva RTV Slovenija. Vsi so bili transkribirani v skladu z vnaprej določenimi načeli, pri čemer smo izhajali iz protokolov, ki jih je razvila konverzacijska analiza, prilagojenih slovenskemu jeziku in namenom raziskave (gl. Lengar Verovnik 2012: 40-42, 49-60).

Transkripcija, kot jo uporablja konverzacijska analiza, ni zgolj reprezentacija govorjenega dialoga, temveč poskuša zajeti še relevantne prvine neverbalne interakcije, pa tudi prvine, kot so prekrivajoči se govor, premori v posameznih izjavah in med njimi, poudarki ipd. Rezultat je zapis podatkov, ki nima oblike klasičnega besedila, temveč je prej večdimenzionalna notacija podrobnosti konkretnega govornega dogodka. Naše transkripcije $v$ glavi vsebujejo osnovne podatke o kontekstu in govorcih, v besedilu, ki je zapisano v raziskovalnim namenom prilagojeni fonemski transkripciji, pa so označene tudi stavčnofonetične prvine (pri čemer smo izhajali iz že obstoječih praks drugih slovenskih raziskovalcev govora), diskurzivni označevalci (gl. Verdonik 2007 in drugod) in parajezikovne prvine, ki spremljajo ali karakterizirajo govor.

Zgledi, ki bodo navedeni v naslednjem poglavju, niso zapisani z vsemi transkripcijskimi prvinami, zajetimi v izvirne transkripcije. Izpuščene so značilnosti, ki za interpretacijo rezultatov niso relevantne, saj bi lahko oteževale branje.

\subsection{Korpusno gradivo}

Gigafida je pisni korpus slovenskega jezika, ki obsega 1,2 milijarde besed. Vsebuje besedila različnih zvrsti, ki so izšla ali so bila objavljena med letoma 1990 in 2011. Gre za tiskana besedila in besedila, zbrana s spletnih strani. Največ je besedil publicistične zvrsti, sledijo besedila z interneta, stvarna besedila in leposlovje (www. gigafida.net). GOS je korpus govorjene slovenščine, ki obsega transkripcije okoli 120 ur govora v različnih govorjenih diskurzih oziroma okoli 1 milijardo besed. Vsakemu izpisu iz korpusa pripada posnetek, ki ga je mogoče slišati. Tudi v tem korpusu je največ besedil iz medijev (radio, televizija), sledijo osebni stik v zasebnih govornih položajih, osebni javni stik v izobraževanju in osebni nezasebni nejavni stik (www. korpus-gos.net).

Na spletu sta korpusa Gigafida in GOS dostopna prek vmesnika, ki omogoča tudi nekoliko zahtevnejše iskanje. Za proučevanje leksikalnega kritja, ki - kot smo zapisali zgoraj - ni omejeno le na leksikalno raven, sta korpusa Gigafida in GOS primerna le v primerih, ko kot sredstva leksikalnega kritja nastopajo posamezne besede 
ali besedne zveze in/ali ko je mogoče iskalni pogoj dovolj natančno določiti. Zato bomo primerjalno pregledali nekatere take zglede, zlasti njihovo pogostnost in razporeditev po zvrsteh (Gigafida) oziroma vrstah govorjenih diskurzov (GOS), ne pa vseh primerov in skupin leksikalnega kritja, predstavljenih v nadaljevanju. Omejitve za korpusno iskanje bodo predstavljene $\mathrm{v}$ posameznih razdelkih naslednjega poglavja.

\section{Rezultati in diskusija}

\subsection{Nek(i), nekak(o), na nek način in tako rekoč}

Najpogostejša besedna in besednozvezna sredstva leksikalnega kritja v gradivu so bili pridevniški zaimek nek(i) (43 pojavitev), prislovni zaimek oz. prislovna zveza nekak(o) (89 pojavitev) in na nek način (29 pojavitev) ter členki oz. členkovne zveze pravzaprav (37 pojavitev), v bistvu (13 pojavitev) in tako rekoč (5 pojavitev). Členkovna pravzaprav in $v$ bistvu $\mathrm{v}$ radijskih intervjujih nista vedno nastopala $\mathrm{v}$ vlogi sredstev leksikalnega kritja. Žele (2014) členku pravzaprav že slovarsko pripisuje različne pomene: lahko 'poudarja ugotovitev, presojo stanja', 'izraža pridržek' ali pa 'uvaja popravek k že povedanemu'; $v$ bistvu, ki 'pojasnjuje povedano', pa je opredeljen tudi kot sinonim členka pravzaprav. V korpusni del analize ju zaradi te večfunkcijskosti nismo vključili.

Nedoločni zaimek nek(i) Smolej (2006: 160) uvršča med t. i. besedilne aktualizatorje, ki jih opredeljuje kot leksikalna sredstva, ki »pretvarjajo (spreminjajo) slovarsko vrednost (leksema, pred katerim stojijo) v konkretno referenco (pomen) oz. opravljajo vlogo usmerjevalcev/kazalcev na konkretnost/nekonkretnost oz. splošnost predstavljene reference«. Avtorica analizira rabo aktualizatorjev (en) tak, tist, un, en, $n e k(i)$, tale in ta $\mathrm{v}$ zvezi s pridevniki in/ali samostalniki. Ugotavlja, da so v spontanem zasebnem govoru zelo pogosti, v pisnih (knjižnih) besedilih pa bi bila njihova raba opazna in zaznamovana. V našem gradivu se je nek(i) pojavljal zlasti kot sredstvo izražanja nedoločne/približne vrednosti leksema. Zaradi svoje semantične neopredeljenosti (in neopredeljivosti) je učinkovito sredstvo leksikalnega kritja - ko govorec čuti, da mora izraziti pridržek glede izbire vsebine oziroma glede načina ubeseditve:

- Tukaj so tudi $\boldsymbol{e}$ neki strahovi o skrivni privatizaciji $e$ tega $e$ objekta.

- Neke mm ne vem normative ali kakorkoli način dela (.) $m$ verjetno neke sledi boste pustili.

- Samo e nacionalni medij ima neko, $e$ neko zavezo do gledalcev, poslušalcev in tako naprej.

Ena ključnih ugotovitev naše raziskave je, da prihaja na mestih, kjer govorec uporabi leksikalno kritje, do zgoščevanja sredstev, ki ga udejanjajo. V zgornjih primerih se denimo ob nedoločnem zaimku nek(i) pojavljajo še diskurzni označevalci $e(m)$ in ne vem, ki - kot bo opisano v naslednjem podpoglavju - prav tako lahko izražajo zadržek, oklevanje ipd. 
Navajamo še nekaj zgledov za nekako in na nek način, iz katerih je razvidno, da se pojavljata zlasti skupaj z drugimi sredstvi leksikalnega kritja, ki jih bomo analizirali v naslednjih poglavjih (tu so zgolj označeni s polkrepkim tiskom):

- Se pravi, nekako mladinski centri so lahko, pač zdaj bom mogoče em malo sporno rekla, ampak so lahko tudi čisto (..) pozitivne organizacije $\boldsymbol{n} \boldsymbol{e} \uparrow$.

- Ali komu zamerite, da (..) nekako em niste uspeli z novim pač tem razpisom za ravnatelja Drame?

- Je pomen (...) prostovoljcev v Slovenijii (..) nekako em priznan, so dobro sprejeti, jih družba podpira?

- To je pa verjetno (..) tudi na nek način verjetno tudi na nek način ena taka zanimiva izkušnja.

- A se recimo res ne da- kaj pa če bi kolono morda na nek način obrnili, če je cesta zaprta, kaj- kako recimo, se da kaj storit?

- Davčni svetovalci ne, takrat smo vas pravzaprav mediji $\boldsymbol{n e}$, tudi vas pravzaprav na nek način, ni blo znanja v Sloveniji o davkih, o možnostih, davčni svetovalci ste bili pravzaprav neke zvezde.

V korpusih Gigafida in GOS je iskanje pogostnosti in distribucije nedoločnega zaimka nek(i) kot sredstva leksikalnega kritja oteženo zaradi druge pogoste vloge, ki jo zaimek opravlja tudi v našem besedilu. V Smolej (2006) je opredeljena kot poudarjanje nedoločne/splošne smiselne vrednosti leksema. V tej vlogi je nek(i) podoben pogovornemu aktualizatorju en in z njim tudi (vsaj pogojno, kot test, ali gre za prvi ali drugi pomen) zamenljiv. Splošna ugotovitev, ki sledi iz osnovnega iskanja po korpusu Gigafida, je, da je nek(i) tudi v pisnih besedilih pogost (skupaj pol milijona konkordanc) in da je rabljen v vseh zvrsteh. Tudi v korpusu GOS je zadetkov za ročno analizo vlog zaimka nek(i) preveč (1700), vendar se kaže naslednja tendenca, ki bi jo bilo treba še podrobneje raziskati. Največkrat se zaimek pojavlja v javnem informativno-izobraževalnem diskurzu, kar bi lahko pripisali njegovi siceršnji največji zastopanosti v korpusu. Vendar pa je na drugem mestu po rabi nek(i) nejavni nezasebni diskurz, ki ga je v korpusu po deležih manj kot nejavnega zasebnega in javnega razvedrilnega diskurza, v katerih je bilo najmanj primerov rabe zaimka. To lahko kaže na večjo previdnost, večjo potrebo po izražanju relativne ali nedoločne vrednosti leksemov v bolj formalnih ali formaliziranih položajih. Kako je s to ugotovitvijo povezano leksikalno kritje, pa bi pokazala šele natančnejša analiza besedil.

Podobne ugotovitve veljajo za pojavljanje nekako in na nek način v korpusu Gigafida, le da sta redkeje rabljena (okoli 100.000 oziroma okoli 20.000 konkordanc). Tudi v korpusu GOS se potrjuje večja frekventnost (glede na delež besedil) obeh sredstev leksikalnega kritja v javnem informativno-izobraževalnem in nejavnem nezasebnem diskurzu glede na javni razvedrilni in nejavni zasebni diskurz. Ponovimo lahko torej predvidevanje, da je z večanjem formalnosti govornega položaja večja tudi potreba po relativiziranju (moči) izraza ali vsebine, ki ju analizirani izrazi modificirajo. 
Členkovna zveza tako rekoč ima v SSKJ pripisan pomen 'izraža omejitev popolne, dobesedne ustreznosti izraza, resničnosti’, identična je pomenska opredelitev v Žele (2014). Tudi v našem gradivu se je pojavljala v tej vlogi:

- Tako rekoč nepregledne izdaje knjižnih naslovov so vam na voljo, in avtorjev seveda.

- Gospod Virant, zdaj ko je podpis že za vami in se tako rekoč nič več ne more zalomiti, lahko priznate - kaj vam je najbolj pilo kri?

- Vi ste dobili posel, (..) Gorenje izdeluje patrie, ampak jih ne daje vam, da jih vi potem daste obrambnemu ministrstvu, (..) vi ste tisti dobavitelj tako rekoč, ker ste (..) dobili posel, ampak (..) jih izdeluje in pogodba (..) funkcionira samo na relaciji Patria-Gorenje.

Zadnji primer je zanimiv še zaradi dvojega: prvič, v vlogi oklevanja nastopajo neskladenjski (nepričakovani) premori; in drugič, sredstvo leksikalnega kritja je umeščeno za in ne pred vsebino, ki jo modificira. To je v našem gradivu tudi sicer relativno pogost pojav. Kärkkäinen (2010: 224-227) za ameriško angleščino ugotavlja, da je postpozicija najpogostejša $\mathrm{v}$ nenačrtovanem (spontanem) govoru, najredkejša $\mathrm{v}$ načrtovanem (institucionaliziranem, večinoma monološkem) govoru, medtem ko je tematsko usmerjeni govor (večinoma dialoški, kamor sodijo tudi naši intervjuji) po rezultatih na sredini. Vsekakor bi bilo mogoče morebitne prihodnje raziskave usmeriti tudi $\mathrm{v}$ to značilnost.

V korpusu Gigafida je za zvezo tako rekoč okoli 50.000 konkordanc, raba je razporejena po vseh zvrsteh v zaporedju, kakor si sledijo njihovi siceršnji deleži v korpusu. V korpusu GOS je zadetkov le 30, kar kaže na relativno majhno pogostnost tega jezikovnega sredstva $v$ govoru nasploh. Največ primerov rabe je v najbolj zastopanem diskurzu (javni informativno-izobraževalni), v preostalih diskurzih je primerov premalo (po 3 oziroma 2), da bi lahko iz njihovega razmerja karkoli sklepali.

\subsection{Diskurzni označevalci $e, n e$ in ne vem}

Značilno za diskurzne označevalce je, da »k vsebini diskurza ne prispevajo nič ali skoraj nič, imajo pa pomembno pragmatično vlogo, saj povezujejo vsebino, organizirajo potek diskurza, izražajo odnos do sogovornika, do vsebine itd.« (Verdonik in dr. 2007: 19). Polglasniški diskurzni označevalec, zapisan kot e, eee, em ali $m$, je v gradivu sicer večinoma rabljen kot sredstvo glasovnega premora. Novinar ga uporabi, ko razmišlja o nadaljevanju svojega govora, občasno pa je mogoče ob obotavljanju začutiti tudi zadržek glede oblike ali vsebine povedanega, npr.:

- od dneva, ko (.) je minister Erjavec $\boldsymbol{e}$ (.) obelodanil, da ste vi izbrani

- Je pomen (...) prostovoljcev v Slovenijii (..) nekako em priznan, so dobro sprejeti, jih družba podpira?

Tudi tukaj je vidno zgoščevanje sredstev leksikalnega kritja, saj se pred diskurznim označevalcem em pojavi še prislov nekako, v neposredni bližini je rabljen tudi neskladenjski premor. 
Diskurzni označevalec ne, a ne po Verdonik (2007: 66-67) sredi replike zaznamuje preverjanje sogovornikove pozornosti oziroma razumevanja. V našem gradivu je (a) ne rabljen v drugačni vlogi: najpogosteje novinar išče strinjanje s povedanim oziroma izraža negotovost glede povedanega, preverja resničnost navedbe. Ker so sogovorci bodisi kompetentni poznavalci nekega področja (v informativnih in izobraževalnih intervjujih) bodisi novinar govori o podrobnostih iz njihovega življenja (pri osebnostnih intervjujih), je takšna previdnost razumljiva:

- Predstavljam si, da je precej prvinsko tam $\boldsymbol{n} \boldsymbol{e} \uparrow$. Najbrž nimajo računalnikov?

- Ste rešili tudi probleme s tistimi Slovenci, ki delajo v tujini? Predvsem em $\boldsymbol{e}$ Štajerska $\boldsymbol{n} \boldsymbol{\uparrow} \uparrow$ je bila nekoliko problematična in Avstrija.

- Letalska srednja šola $\boldsymbol{n} \boldsymbol{e} \uparrow$, ste rekli, v Mostarju.

Diskurzni označevalec ne je $\mathrm{v}$ tej vlogi praviloma izgovorjen $\mathrm{z}$ rastočo intonacijo (v transkripcijah je označena z znakom $\uparrow$ ), ki je očitno del strategije leksikalnega kritja.

Kot diskurzni označevalec lahko nastopa tudi zveza ne vem, ki je sorodna izrazom bom rekel, če tako rečem ipd., ki jih bomo obravnavali v naslednjem podpoglavju. Ne vem je sredstvo ohranjanja govorne vloge in hkrati signal oklevanja - z njim novinar sogovorcu signalizira, da išče ustrezni izraz in/ali da pri tem okleva. V tem je podoben tudi diskurznemu označevalcu $e$, le da je bolj določen.

- Kateri pa so torej vsi ti preparati, ki bi jih (.) morali imeti (.) u domači (.) ne vem nočni omarici?

- Kaj pa če to ni izvedljivo, da je tist že, ne vem, hujši stadij?

- zakaj ee Durs ne upošteva tistega ne vem izračuna ali računa, ki je bil naveden v preteklosti $e$ na dohodninski napovedi?

Ker gre pri diskurznih označevalcih za izrazito govorna sredstva, njihove prisotnosti v korpusu Gigafida nismo preverjali. Njihov morebitni zapis po naših predvidevanjih namreč pomeni zgolj prenos govorne prvine v pisni žanr z namenom stilnega učinkovanja ali pa - pri zapisih na spletu (forumih, komentarjih pod članki) - predstavlja konstitutivno žanrsko prvino. V korpusu GOS je diskurzni označevalec $e$ zapisan z eno ali več (do 4) črkami $e$, dvočrkjem em ali črko $m$. Teoretično bi torej lahko v korpusu raziskovali tudi vlogo tega diskurznega označevalca pri leksikalnem kritju, a ker je to le ena od mnogih vlog (gl. Verdonik 2007; Lengar Verovnik 2012), ki jih lahko opravlja, bi bilo treba ročno pregledati vse zglede. Podobno velja za diskurzni označevalec ne, kjer bi bilo treba poleg besedilne analize vključiti še avditivno, saj bi šele poslušanje transkripcijam pridruženih posnetkov pokazalo, kako pogosto je rastoča intonacija spremljevalec ne kot sredstva leksikalnega kritja. Zveza ne vem ima v korpusu GOS okoli 2700 pojavitev. Čeprav bi bilo treba za razločitev rabe $v$ dobesednem pomenu ('ne vedeti') od rabe izraza kot diskurznega 
označevalca pregledati vse zglede, pa že pregled prvih 100 konkordanc pokaže znatno prisotnost druge rabe, tj. signala omahovanja, oklevanja. Zanimivo je, da za razliko od jezikovnih sredstev iz 4.1 - tukaj prevladujejo nejavni diskurzi (tako zasebni kot nezasebni). Ločnica torej ni večja/manjša formalnost, temveč javnost/ zasebnost govornega položaja.

\subsection{Zveze z glagolom reči}

Zveze bom rekel (38 pojavitev), lahko rečem (16 pojavitev), bi rekel (13 pojavitev), če tako rečem (6 pojavitev) (zajete so tudi prvoosebne dvojinske in množinske oblike) ipd. sogovorca in poslušalce opozarjajo na zaznamovanost že povedanega oziroma tega, kar v govoru sledi. Pri tem ni pomembno, za katere vrste zaznamovanost gre in ali je zaznamovana raven jezikovnih izbir ali vsebine.

- Nekaj, bom rekel, precej frapantnih številk ste tam tudi obdelovali

- Verjetno pa morate prostovoljci biti prav posebne vrste ljudje $\boldsymbol{n} \boldsymbol{e} \uparrow$, če tako rečem.

- S kom imate pravzaprav več dela, bi rekla, s tistim, ki vara, ali s tistim, ki je prevaran?

Tudi v teh primerih je vidno zgoščevanje sredstev leksikalnega kritja: neposredno ob zvezah z glagolom reči ali ob zaznamovanih izrazih/zvezah so uporabljeni še precej, pravzaprav, $e$ in ne.

Od izbora zaznamovanega izrazja se lahko novinar tudi distancira, in sicer tako, da uporabi v besedni zvezi z glagolom reči vključujočo prvo osebo dvojine ali množine:

- Ker təm pet šest ur stat $\mathrm{v}$ koloni, to je res $\boldsymbol{e}$ višek, lahko rečemo ne $\uparrow$.

- Da so zaradi tega pač ti poklici zašli v, kot temu rečemo, deficitarne vode. (...) Da jih premalo plačajo, po domače povedano.

$\mathrm{V}$ drugem primeru uporabi novinar $\mathrm{v}$ naslednji povedi še parafrazo domnevno zaznamovanega izraza »deficitarne vode«, ki ji doda metakomentar »po domače povedano« (več o tej vrsti sredstev leksikalnega kritja v podpoglavju 4.4).

Iskanje po korpusu Gigafida daje pri tej skupini zvez dobre rezultate tam, kjer je mogoče karseda natančno formulirati iskalni pogoj. Zveze »če tako rečem(o)« smo iskali z vnosom iskalnega pogoja 'če tako reči' (ob tem je sicer mogoče dobiti tudi zveze tipa »če tako reče ona«, a so te le izjema). Najdenih primerov je okoli 600 , polovica od tega $\mathrm{z}$ interneta, nekaj manj kot polovica iz publicistike, $\mathrm{v}$ stvarnih besedilih primerov ni, nekaj jih je iz leposlovja. Med primeri z interneta je opazno, da so skoraj vsi zgledi iz transkripcij govora v Državnem zboru RS. Izrazita navezava na govor je razvidna tudi iz publicističnih primerov, saj hiter pregled pokaže, da se večinoma pojavljajo v dobesednih navedkih ali v pisnih intervjujih. Podobno je v sicer maloštevilnih primerih iz leposlovja, ki so vezani na dobesedno navajanje ali notranji monolog. Nekoliko drugače je z razširjeno zvezo »če lahko tako rečem(o)«: primerov 
je še več (okoli 800), več jih je v publicistiki kot na internetu (tu spet prevladuje govor v Državnem zboru RS), kadar so zveze edninske, pa so spet vezane na dobesedno navajanje ali intervjujske in podobne žanre. Pri zvezi »bom rekel« ipd. smo iskanje omejili s pogoji ', bom rekel,' oz. ', bom rekla,' oz. ', bomo rekli,'. Pokazalo se je namreč, da zveze, ki v pisanju niso omejene z vejicami, praviloma nimajo pomena leksikalnega kritja. Rezultati so pokazali prevladujočo navezavo na govor: od okoli 2300 primerov jih je bila večina $z$ interneta, in sicer iz Državnega zbora RS, le peščica se jih je pojavila na novičarskih portalih ali sploh v drugih zvrsteh. Pri zvezi »bi rekel« ipd. je analiza zveze kot sredstva leksikalnega kritja otežena z drugimi pomeni in vlogami, zato bi bilo treba gradivo pregledati ročno.

V korpusu GOS se zveza »če (lahko) tako rečem(o)« pojavi le 10-krat (razen enega primera vedno v javnih diskurzih). Več pojavitev je pri zvezi »bom rekel«ipd. (okoli 160), kjer ne gre vedno za opravljanje vloge sredstva leksikalnega kritja, je pa ta prevladujoča. Največ pojavitev je v javnem informativno-izobraževalnem in nejavnem nezasebnem diskurzu, kar kaže na večjo prisotnost v bolj formalnih govornih položajih. Za zvezo »bi rekel« ipd. pa velja enako kot pri pisnem korpusu: najdenih 260 primerov bi bilo treba pregledati ročno, da bi lahko izluščili in nato tudi analizirali primere, ko se zveza uporablja kot leksikalno kritje, saj je nabor rab po hitrem pregledu gradiva skladenjsko in pomensko zelo pester.

\subsection{Narekovaji in navednice}

Narekovaji in navednice se v radijskih intervjujih sicer niso pojavljali pogosto ( $3 \mathrm{oz}$. 1 pojavitev), a so zanimivi, saj bi naslednje zglede na prvi pogled lahko pripisali tudi prilagojenosti govornemu prenosniku (v smislu, ker poslušalec ločil ne more videti, jih novinar pač ubesedi):

- Se to vaše delo, to vaše izkušnje, potem lahko kje, da rečem tako v narekovajih, unovči?

- Glasovi so bili pa n- v tej smeri, da ste se, $\mathbf{v}$ narekovajih seveda, zapodili v najbolj vitalen del (.) hiše, se pravi novinarje

- Ali morda vidite (..) v sedanji vojni proti, v navednicah rečeno, proti direktorjem, ki so prevzeli podjetja, tudi (..) ne samo predvolilno zgodbo

Vendar so tovrstne prilagoditve na radiu predvidene zlasti pri govorjenju po pisni predlogi (največkrat branju), o čemer v zgornjih primerih ne moremo govoriti. Bolj verjetna je interpretacija, da novinar $\mathrm{v}$ trenutku ubesedovanja pomisli na to, da bo njegov leksikalni izbor na sogovorca in/ali poslušalce deloval preveč zaznamovano (gosta morebiti celo užalil) ali pa da ne bo ustrezno - torej aktualizirano - razumljen. Narekovaji in navednice so torej le stopnja več kot bom rekel ipd.; so signal za gosta in poslušalca, naj leksikalni izbor razume kot nameravani stilem, kot sredstvo ekspresije (in ne morda žalitve).

V korpusu Gigafida se najpogosteje pojavlja zveza »v narekovajih«, ki ima okoli 750 pojavitev. Polovica zgledov je z interneta, malo manj kot polovica iz publicistike. 
Od spletnih pojavitev jih je največ iz transkripcij govora v Državnem zboru RS, druge so z novičarskih portalov, predvidoma iz komentarjev uporabnikov, kjer gre za pogoste prenose zasebnih govornih praks v pisanje (predvidoma tudi pri teh zvezah). $\mathrm{V}$ gradivu $\mathrm{z}$ interneta se zveza največkrat rabi $\mathrm{v}$ prenesenem pomenu ('reči, misliti kaj, kot bi bilo zapisano med narekovaji'), tudi v publicističnih besedilih ta pomen prevladuje. Podobno je pri zvezi »v navednicah«, ki je sicer redkeje rabljena (okoli 230 pojavitev): polovica rab je na internetu, malo manj kot polovica v publicistiki, z že opaznejšo dobesedno rabo (najbrž zaradi večje formalnosti izraza navednice glede na narekovaji). Zvezi »med narekovaji« in »med navednicami« sta najmanj pogosti (okoli 40 oziroma 30 primerov). Prva je prevladujoče rabljena v stvarnih besedilih, in sicer v dobesednem pomenu, druga je pogostejša na internetu in v publicistiki, a tudi tu redkeje $\mathrm{v}$ prenesenem pomenu.

Da sta ti zvezi izraziteje vezani na dobesedni pomen in s tem na pisanje, potrjuje gradivo v korpusu GOS. Zvezi »med narekovaji« in »med navednicami« se namreč v njem sploh ne pojavita, zvezi »v narekovajih« (11 pojavitev) in »v navednicah« (3 pojavitve) pa sta vedno rabljeni v prenesenem pomenu. Zanimivo je tudi, da sta obe omejeni na rabo $v$ javnih govornih položajih, saj so vsi primeri iz javnega informativno-izobraževalnega oziroma razvedrilnega diskurza.

\subsection{Metakomentarji leksikalnih izbir}

Novinarji se morajo ves čas zavedati in s svojim govornim ravnanjem tudi kazati, da je glavna oseba $v$ intervjuju sogovorec. To pomeni, da se morajo v nagovorih nenehno samoomejevati in iz njih izključevati komentarje, mnenja, lastne vrednostne sodbe in podobno. Da se zavarujejo pred morebitnim napačnim razumevanjem, nenameravano žalitvijo, nerazumljeno ekspresivnostjo ipd., poleg do sedaj naštetih sredstev leksikalnega kritja uporabljajo tudi t. i. metakomentarje leksikalnih izbir. Ti se pojavljajo, ko novinar začuti, da mora izraziti bolj določen pridržek glede načina ubeseditve oziroma izbire vsebine, kot ga omogočajo prej obravnavana sredstva. Pogosto je metakomentar zato opis ozadja, motivov, razlogov za izbor:

- Zdaj že dolgo časa, to je vaša misel, ne skladiščite več teh ljudi ((skozi rahel smeh)) ne v nekem nesmiselnem brezdelju in pasivnosti.

- Gospa Ana Božičnik je naša gostja, z direktorata za turizem, bom (..) se čisto po natakarsko izrazil: zadnja ((skozi rahel smeh)) runda, gospa Božičnik.

- In se seveda dogaja tudi to, da starši, ki formalno sicer $e$ ustrezajo pogojem za določitev najnižjega razreda denimo $a$ ne, za najnižje plačilo vrtca, vozijo (..) zelo dober avto, če poenostavim, a ne.

- Ste kaj dlje od samo razpisa ali kaj bližje temu, da bi vzpostavili sistem, ki ne bi (.) bil recimo tako na robu zmogljivosti, če temu najbolj prijazno lahko rečem.

- Tako klišejsko (.) se sliši, če rečem, v zibelko vam je bila (.) položena humanitarnost, dobrodelnost, pomoč sočloveku, ampak vam je (.) res skorajda dobesedno bila a ne. 
Poleg drugih sredstev leksikalnega kritja (premori, a ne) je v dveh primerih opazna tudi prisotnost parajezikovne prvine, smeha. Čeprav novinarja z metakomentarjem opozarjata na zunanje avtorstvo »spornih« zvez, pa s tem bržkone kažeta zadovoljstvo z lastno kreativnostjo v procesu tvorjenja sporočila. Ta vrsta sredstev leksikalnega kritja je tudi sicer izrazito vezana na širši kontekst sporočanja, zato jo je nemogoče preverjati v korpusnem gradivu.

\subsection{Leksikalno kritje in vljudnost}

V zvezi z izražanjem vljudnosti se na splošno ugotavlja, da je raba sredstev leksikalnega kritja ena najpomembnejših vljudnostnih strategij: ta sredstva omilijo izjave in zmanjšujejo tveganost izrečenega. V tej vlogi se pojavljajo v vseh govornih interakcijah, torej tudi v intervjujih. Kadar bi lahko neko vprašanje ogrozilo ugled (družbeno pomembne) osebnosti, leksikalno kritje vsebino ublaži in jo vsaj na površini omili.

Edini te vrste $v$ našem gradivu je bil naslednji izsek. V njem novinarka kot sredstvo leksikalnega kritja uporablja trpniške zgradbe (ta vloga trpnika je v literaturi pogosto omenjena), namesto neposrednega nagovora pa uporablja tretjo osebo za sicer prisotnega sogovorca:

- Odstop, večkrat napovedan, načelen, nenačelen, o tem se je veliko govorilo, veliko pisalo. $e$ Še v petek v časopisih so izšla razmišljanja o tem, ali bo res odstopil ali ne bo našel nekega drugega razloga. Kaj je pravzaprav (.) pripeljajo Ivana Simiča, da je po dveh letih in pol rekel, dovolj je?

Tovrstne strategije omogočajo novinarju poleg izražanja vljudnosti tudi ustvarjanje distance med sabo in svojo nalogo, tj. obveščanjem javnosti o zanjo relevantnih zadevah. McVittie in dr. (2011) pišejo, da ima novinar v primeru, ko sogovorca ne želi neposredno izzvati z neprijetno temo, na voljo tudi druge možnosti. Vprašanje lahko pripiše drugemu viru - na primer navede citat iz časopisa in prosi sogovorca za komentar. Lahko se tudi sklicuje na »ljudi« ali »javnost« ali pa uporablja naklonske izraze (za slovensko poročevalstvo značilna zveza te vrste je npr. naj bi + deležnik na -l; gl. Korošec 1998).

\section{Zaključek}

Analiza govora novinarjev v intervjujih z javnih radijskih programov Slovenija 1 in Val 202 je pokazala, da so strategije leksikalnega kritja pogoste ter skladne z žanrskimi in diskurzivnimi značilnostmi intervjuja (empatičnost do sogovorca, zavedanje institucionalne vloge in omejitev, ki izhajajo iz nje, previdnost pri izražanju neposrednih sodb, lastnih komentarjev in mnenj oziroma izjav, ki bi lahko bile kot take razumljene ali bi gosta užalile, ga spravile v neprijeten položaj, delovale nevljudno 
ipd.). Sredstva, ki jih novinarji uporabljajo za leksikalno kritje, so zelo raznolika in jih najdemo na vseh ravneh, ki so jih identificirale že druge raziskave: na ravni posameznih besed in besednih zvez (npr. nekako, v narekovajih), na leksikalno-skladenjski (npr. bom rekel/bova rekla/bomo rekli) in oblikoslovni ravni (npr. izbira trpniške namesto tvorne oblike glagola), na ravni stavčne fonetike (npr. rastoča intonacija ob diskurznem označevalcu ne) ter na ravni diskurznih označevalcev (npr. $e$, ne vem) in samostojnih delov povedi (t. i. metakomentarjev leksikalnih izbir, gl. 4.5). Zanimiva je ugotovitev, ki izhaja iz pregleda celotnega gradiva: da sredstva leksikalnega kritja navadno ne nastopajo sama, temveč se na mestu oklevanja, negotovosti, (samo)omejevanja ipd. raba raznolikih sredstev zgosti. Temu bi lahko v prihodnje posvetili več raziskovalne pozornosti; prav tako bi bilo treba podrobneje analizirati pozicije sredstev leksikalnega kritja v besedilih: ali so pred ali za delom, ki ga modificirajo; kolikšen doseg imajo, kadar zgolj spremljajo osrednje sredstvo leksikalnega kritja (v primeru omenjenega zgoščevanja).

Pri iskanju po korpusih Gigafida in GOS se je pokazalo, da tovrstna analiza ni mogoča ali primerna za vsa sredstva leksikalnega kritja. O primerih, ki jih je bilo mogoče dovolj dobro definirati že z iskalnim pogojem (npr. bom rekel ipd.), lahko dobimo glede rabe $\mathrm{v}$ različnih zvrsteh in diskurzih - primerjalno $\mathrm{z}$ gradivom iz intervjujev - dovolj dobro predstavo. Pri drugih je mogoče razmerje med različnimi možnimi rabami oceniti že s hitrim pregledom konkordanc, večinoma pa bi bilo treba iskanje, ki ga omogoča vmesnik, dopolniti s podrobnejšo analizo besedilnih izsekov. Groba primerjava z gradivom korpusov Gigafida in GOS razkriva, da so nekatera sredstva leksikalnega kritja, ki so se pojavljala $\mathrm{v}$ analiziranih radijskih intervjujih, lahko tako pisna kot govorna (npr. nek(i), nekako, na nek način), nekatera pa so celo bolj vezana na pisne žanre (tako rekoč, v navednicah). Pri sredstvih, ki so se tudi v korpusnem gradivu relativno pogosto (ali pogosteje kot $\mathrm{v}$ pisnem) pojavljala $\mathrm{v}$ govornem gradivu, pa se kažejo tri skupine, ki bi jih bilo zanimivo podrobneje raziskati: sredstva, ki so vezana na bolj formalne položaje (tako javne kot zasebne), npr. bom rekel, neki, nekako, na nek način; sredstva, ki so vezana na javne položaje (tako informativno-izobraževalne kot razvedrilne), npr. če (lahko) tako rečem(o), v narekovajih, $v$ navednicah; sredstva, vezana na nejavne položaje (tako zasebne kot nezasebne), tak je bil v gradivu le diskurzni označevalec ne vem. Za intervjuje lahko trdimo, da so presečišče vsega trojega: formalnega, javnega in (omejenega prenosa iz) zasebnih govornih praks (več o tem v Lengar Verovnik 2012), zato prekrivnost s temi tremi skupinami rezultatov iz korpusne gradivne analize ni presenetljiva. 


\section{Bibliografija}

Adams, Sally. 2005. Interviewing for Journalists. London, New York: Routledge.

Bradac, James J., Anthony Mulac in Sandra A. Thompson. 1995. Men's and Women's Use of Intensifiers and Hedges in Problem-Solving Interaction: Molar and Molecular Analyses. Research on Language and Social Interaction 28 (2): 93-116.

Crompton, Peter. 1997. Hedging in Academic Writing: Some Theoretical Problems. English for Specific Purposes 16 (4): 271-287.

Farr, Fiona in Anne O'Keeffe. 2002. Would as a hedging device in an Irish context: An intra-varietal comparison of institutionalised spoken interaction. V Randi Reppen in dr. (ur.), Using Corpora to Explore Linguistic Variation, 25-48. Amsterdam, Philadelphia: John Benjamins.

Fetzer, Anita. 2010. Hedges in Context: Form and Function of Sort of and Kind of. V Kaltenböck in dr. (ur.), New Approaches to Hedging, 49-72. Bingley: Emerald.

Fraser, Bruce. 2010a. Pragmatic Compeence: The Case of Hedging. V Kaltenböck in dr. (ur.), New Approaches to Hedging, 15-34. Bingley: Emerald.

Fraser, Bruce. 2010b. Hedging in political discourse: The Bush 2007 press conferences. V Urszula Okulska in Piotr Cap (ur.), Perspectives in Politics and Discourse, 201-214. Amsterdam; Philadelphia: John Benjamins Publishing.

Gabrovšek, Dušan in dr. 2005. Veliki angleško-slovenski slovar. Knjiga 1: A-K. Ljubljana: DZS.

Gries, Stefan Th. in Caroline V. David. 2007. This is kind of / sort of interesting: variation in hedging in English. Studies in Variation, Contacts and Change in English 2: Towards Multimedia in Corpus Studies. Dostopno prek: www.helsinki.fi/varieng/series/volumes/02/gries_david/ (12.2. 2015).

Jalilifar, A. R. in M. Alavi. 2011. Power and Politics of Language Use: A Survey of Hedging Devices in Political Interviews. The Journal of Teaching Language Skills 3 (3): 43-66.

Kaltenböck, Gunther, Wiltrud Mihatsch in Stefan Schneider. 2010. Introduction. V Kaltenböck in dr. (ur.), New Approaches to Hedging, 1-14. Bingley: Emerald.

Kärkkäinen, Elise. 2010. Position and Scope of Epistemic Phrases in Planned and Unplaned American English. V Kaltenböck in dr. (ur.), New Approaches to Hedging, 203-236. Bingley: Emerald.

Korošec, Tomo. 1998. Stilistika slovenskega poročevalstva. Ljubljana: Kmečki glas.

Korpus Gigafida $=<\mathrm{http}: /$ www.gigafida.net $>$

Korpus govorjene slovenščine GOS $=<\mathrm{http}: / /$ www.korpus-gos.net $>$

Košir, Manca. 1988. Nastavki za teorijo novinarskih vrst. Ljubljana: Državna založba Slovenije.

Laban, Vesna. 2007. Televizijsko novinarstvo: hibridizacija žanrov in stilov. Ljubljana: Fakulteta za družbene vede.

Lakoff, George. 1972. Hedges: A study in meaning criteria and the logic of fuzzy concepts. V Paul M. Peranteau in dr. (ur.), Papers from the 8th Regional Meeting, 183-228. Chicago: Chicago Linguistics Society.

Lakoff, Robin. 1975. Language and Women's Place. New York: Harper and Row.

Lengar Verovnik, Tina. 2012. Radijska dvogovornost: jezikovne izbire novinarjev. Elektronski vir. Ljubljana: Fakulteta za družbene vede, Založba FDV.

McVittie, Chris, Rahul Sambaraju in Andy McKinlay. 2011. "There Will Only Be Lots of Chit-Chat": How Hamas Leaders and Media Interviewers Handle Controversial Topics. Research on Language \& Social Interaction 44 (1): 92-105.

Pisanski Peterlin, Agnes. 2010. Hedging devices in Slovene-English translation: a corpus-based study. Nordic journal of English studies 9 (2): 171-193. 
Pisanski Peterlin, Agnes. 2007. Raziskave metabesedilnosti v uporabnem jezikoslovju: pregled področja in predstavitev raziskovalnega dela za slovenščino. Jezik in slovstvo 52 (3/4): 7-19.

Poos, Deanna in Rita Simpson. 2002. Cross-disciplinary comparisons of hedging: Some findings from the Michigan Corpus of Academic Spoken English. V Randi Reppen in dr. (ur.), Using Corpora to Explore Linguistic Variation, 3-24. Amsterdam, Philadelphia: John Benjamins.

Smolej, Mojca. 2006. Vpliv besedilne vrste na uresničitev skladenjskih struktur (primer narativnih besedil v vsakdanjem spontanem govoru. Doktorska disertacija. Ljubljana: Filozofska fakulteta.

Verdonik, Darinka. 2007. Jezikovni elementi spontanosti v pogovoru. Maribor: Slavistično društvo.

Verdonik, Darinka, Andrej Žgank in Agnes Pisanski Peterlin. 2007: Diskurzni označevalci v dveh pogovornih žanrih. Jezik in slovstvo 52 (6): 19-33.

Verschueren, Jef. 2000. Razumeti pragmatiko. Ljubljana: Založba *cf.

Žele, Andreja. 2014. Slovar slovenskih členkov. Ljubljana: Založba ZRC.

Prispelo marca 2015, sprejeto maja 2015

Received March 2015, accepted May 2015

\section{Strategije in sredstva leksikalnega kritja v radijskih intervjujih}

Leksikalno kritje (angl. hedging) je bilo izvorno opredeljeno kot raba jezikovnih sredstev, »katerih vloga je stvari v besedilu zamegliti ali jih narediti razvidnejše« (Lakoff 1972: 195). Prvotna definicija pojava je ob širjenju področij raziskovanja doživljala mnoge konceptualne dopolnitve in spremembe. Čeprav so posamezne opredelitve odvisne tudi od raziskovalčevega namena, metode raziskovanja in tipa diskurza, se pojem leksikalno kritje v sodobnih virih nanaša pretežno na prvi del izvorne definicije. Sredstva leksikalnega kritja niso zaključena množica. Skupno jim je, da delujejo kot opozorilo govorca/pisca, da želi bodisi omejiti vsebino ali ublažiti ilokucijsko moč povedanega. Nobeno jezikovno sredstvo torej ni samo po sebi sredstvo leksikalnega kritja, ampak to postane šele $v$ določenem sporočanjskem kontekstu in je za tak kontekst tudi tipično (medtem ko lahko v drugih kontekstih opravlja druge vloge). Pojav se je kot uporaben izkazal pri proučevanju izražanja (ne)vljudnosti, pri proučevanju izražanja $\mathrm{v}$ znanstvenih diskurzih, pri medjezikovnih in medkulturnih analizah, pri poučevanju tujih jezikov in jezikovnih razlik glede na spol govorca ter pri primerjalnih analizah govora in pisanja oziroma pri raziskovanju zgolj govora.

$\mathrm{V}$ tem prispevku se omejujemo na govor novinarjev $\mathrm{v}$ radijskih intervjujih $\mathrm{z}$ dveh programov slovenskega javnega radijskega servisa. Radijski intervjuji predstavljajo diskurz, v katerem je novinar kot spodbujevalec pogovora med drugim zavezan empatičnosti do sogovorca in občinstva, kar pomeni veliko verjetnost za rabo strategij in sredstev leksikalnega kritja. V empiričnem delu na gradivu radijskih 
intervjujev s slovenskega javnega servisa analiziramo primere leksikalnega kritja, jih kategoriziramo glede na njihove pojavne oblike in z upoštevanjem diskurzivnih okoliščin poskušamo utemeljevati motive zanje. S primerjavo z gradivom iz pisnega korpusa Gigafida in korpusa govorjene slovenščine GOS preverjamo tudi njihovo (ne)tipičnost za radijske intervjuje oziroma njihovo (ne)prekrivnost $\mathrm{z}$ rabo $\mathrm{v}$ pisnih in drugačnih govorjenih diskurzih. Analiza kaže, da so strategije leksikalnega kritja pogoste ter skladne z žanrskimi in diskurzivnimi značilnostmi intervjuja. Sredstva, ki jih novinarji uporabljajo za leksikalno kritje, so zelo raznolika in jih najdemo na vseh ravneh, ki so jih identificirale že druge raziskave. Zanimiva je ugotovitev, ki izhaja iz pregleda celotnega gradiva: da sredstva leksikalnega kritja navadno ne nastopajo sama, temveč se na mestu oklevanja, negotovosti, (samo)omejevanja ipd. raba raznolikih sredstev zgosti. Primerjava z gradivom korpusov Gigafida in GOS razkriva, da so nekatera proučevana sredstva leksikalnega kritja tako pisna kot govorna, nekatera pa celo bolj vezana na pisne žanre. Pri sredstvih, ki se relativno pogosto (ali pogosteje kot v pisnem) pojavljajo v govornem gradivu, pa se kažejo tri skupine, ki bi jih bilo treba podrobneje raziskati: sredstva, ki so vezana na bolj formalne položaje (tako javne kot zasebne); sredstva, ki so vezana na javne položaje (tako informativno-izobraževalne kot razvedrilne); sredstva, vezana na nejavne položaje (tako zasebne kot nezasebne). Pri iskanju po korpusih se je pokazalo, da tovrstna analiza ni mogoča ali primerna za vsa sredstva leksikalnega kritja; pri nekaterih bi bilo treba iskanje, ki ga omogoča vmesnik, dopolniti s podrobnejšo analizo besedilnih izsekov.

\section{Hedging strategies and linguistic devices in radio interviews}

Traditionally, hedges were defined as words or phrases »whose job it is to make things fuzzier or less fuzzy« (Lakoff 1972: 195). The concept of hedging has since undergone considerable changes. The use of the term today in all areas of hedging research deals almost exclusively with the first part of the original definition, i.e., with lack of commitment, attenuation (although different interpretations of the term's range and content may depend on the scope, method and goals of a specific research). Hedges do not form a uniform category and they only become hedging devices when they are used as such. By including a particular term, choosing a particular structure, or imposing a specific prosodic form on the utterance, the speaker signals the attenuation of the full value which the utterance would have (either on the content or the illocutionary force level), absent the hedging. The research in the field has focused on different aspects of hedging: its role in scientific texts and discourses, the use of hedges to accomplish politeness, their distribution and use in different languages and socio-cultural contexts, even its association to gender.

This contribution examines hedging strategies and devices employed by journalists in selected interviews from two Slovene public radio programmes. Radio interviews form a specific type of discourse, in which the journalists act as highly 
sensitive and emphatic motivators of the two-way communication, listened to by the public. Therefore use of the hedging strategies and devices is highly probable. In the analysis of the selected interviews, genre and discourse frameworks are taken into account, as they determine journalists' linguistic choices in general. The results are then compared to those from two Slovene language corpora, namely Gigafida (corpus of written texts) and GOS (corpus of oral communication), in order to determine how typical of radio interviews the hedging devices in question are. The analysis shows compliance of the hedging strategies with the genre and discourse characteristics of radio interviews. Hedging devices used in the interviews fall into different categories and belong to different levels of language structure (morphological, lexical, syntactical and prosodic). It is interesting to note that hedges usually do not appear individually, but are accompanied by several other hedges, a phenomenon we provisionally call hedging thickening. A comparison with the results from corpora Gigafida and GOS reveals that some hedging devices can be both written and oral, whereas others are either bound to written communication only or are more frequently (or solely) used in oral communication. This last group is comprised of three subcategories that need further research: hedging devices bound to formal discourse (either public or private), devices bound to public discourse (informative and educational) and those bound to private discourse (formal and nonformal). Corpus analysis proves to be effective only in cases where the search can be narrowed down in the first place; other results need additional textual analysis. 